Reprod. Nutr. Dévelop., 1985, 25 (2), 411-425.

\title{
Addition of sorbitol to a milk substitute for veal calves. - II. Effects on plasma, liver and muscle lipids
}

\author{
D. BAUCHART, B. AUROUSSEAU, E. AUCLAIR, Anne LABARRE (**)
}

with the technical assistance of Françoise DUBOISSET, C. LEOTY, C. MARPILLAT $\left(^{*}\right), J$. MOULY $\left(^{*}\right)$ and R. SOUCHET

Laboratoire d'Etude du Métabolisme énergétique

(*) Laboratoire de la Digestion des Ruminants

I.N.R.A., 63122 Ceyrat, France

(**) Laboratoire d'Anatomie pathologique

Ecole Nationale Vétérinaire, 94701 Maisons-Alfort.

Summary. Two homologous groups of preruminant male calves $(10$ control and 9 sorbitol) of the Friesian $\times$ Holstein crossbreed were used to study the effects of sorbitol on lipid metabolism. Between 1 and 8 weeks of age they received two diets (IC, IS) with high levels of protein and fat ( $23 \%$ of DM), and then between 8 and 19 weeks two diets (FC, FS) containing lower levels of protein and fat ( $21 \%$ of DM). Diets IC and FC contained no sorbitol, while in the IS and FS diets it accounted for $0.8 \%$ of DM.

Blood samples were taken at 2, 3, 4, 7, 12 and 19 weeks of age and the following times : $2 \mathrm{~h}$ before (T-2), and then $1 / 2$ (T1/2), 2 (T2), 3 (T3), 5 (T5) and 7 (T7) hours after ingestion of the morning meal. At slaughter (19 weeks), samples of liver and of rectus abdominis muscle were taken from the carcasses.

The addition of sorbitol to the replacer milks had no effect on plasma levels of nonesterified fatty acids or triglycerides. However at weeks 2, 7 and 12, the levels of free and esterified cholesterol decreased significantly by a mean of 60 and $15 \%$ respectively.

Sorbitol intake significantly reduced muscle levels of triglycerides $(6.8 \mathrm{mg} / \mathrm{g}$ of fresh tissue vs $18.6 \mathrm{mg} / \mathrm{g})$, free cholesterol $(0.41 \mathrm{mg} / \mathrm{g} v s \quad 0.66)$ and total lipids $(13.6 \mathrm{mg} / \mathrm{g} \mathrm{vs}$ 26.1).

Lipid composition of liver was not modified by sorbitol ingestion. An histological study confirmed that the diets caused no serious lesions.

Generally, the results were more dispersed in the control group than in the sorbitol group.

\section{Introduction.}

In adult cattle (Frahm, Graf and Krausslich, 1977) and in rats (Hers, 1954), dietary sorbitol is mainly converted into fructose through the action of hepatic sorbitol dehydrogenase. This also seems to apply to preruminant calves since fructosemia increases after intravenous sorbitol administration (Kouider, Kolb and Müller, 1980) or a few days after sorbitol intake (Daniels et al., 1981). 
The addition of sorbitol to the feed of young preruminant calves (Daniels et al., 1981 ; Thivend, 1982 ; Bauchart, Aurousseau and Auclair, 1985) improves feed conversion ratio and health status and decreases the risk of diarrhoea ; it also alleviates metabolic disorders associated with the intake of high-lipid milk replacers and can improve hepatic functions, as in humans (Hoshi, 1963). Thivend et al. (1984) showed that the amount of biliary organic matter excreted increased by $60 \%$ in calves offered $0.1 \mathrm{~g}$ of sorbitol/day $/ \mathrm{kg}$ liveweight.

Hepatic triglyceride synthesis can be intensified in rats since sorbitol is converted into fructose and then into 3-glycerophosphate (Bassler and Stein, 1967), and phosphatidate phosphohydrolase, a key control enzyme involved in triglyceride synthesis, is enhanced (Sturton et al., 1978). Moreover, in 2-week old preruminant calves (Bauchart, 1983), sorbitol intake leads to a decrease in cholesterolemia and ester-cholesterolemia as in humans (Berg, Matskies and Bergner, 1973).

The aim of the present work was to study the effects of sorbitol intake on lipid metabolism in preruminant calves fed a high-lipid milk substitute from 1 week of age up to slaughter at $180-200 \mathrm{~kg}$ of body weight. Variations the main plasma lipid concentrations were measured from $2 \mathrm{~h}$ before to $7 \mathrm{~h}$ after the meal at different stages of growth between 2 and 19 weeks of age. Hepatic and muscle lipid content and composition as well as hepatic cell histology were studied. Growth and feed utilization in these calves have been described previously (Bauchart, Aurousseau and Auclair, 1985).

\section{Material and methods.}

Animals and feed. - Two groups of 10 (control group C) or 9 (sorbitol group S) preruminant calves were used. From the age of 8 days and during the first 7-week period they were fed two different milk substitutes (initial diets ; control $=$ IC, sorbitol $=$ IS) containing about $230 \mathrm{~g}$ of protein and fat $/ \mathrm{kg}$ of dry matter. During a second 12-week period, they were fed two milk replacers (finisting diets : control $=F C$, sorbitol $=F S$ ) containing about $210 \mathrm{~g}$ of protein and fat $/ \mathrm{kg}$ of dry matter. The experimental diets IS and FS were obtained by substituting sorbitol for starch in the control diets at a rate of $0.8 \%$ of dry matter. Feed composition and animal management have already been described (Bauchart, Aurousseau and Auclair, 1985).

Blood, liver and muscle samples. - Blood samples $(20 \mathrm{ml})$ were obtained from each calf at $2,3,4,7,12$ and 19 weeks of age $2 \mathrm{~h}$ before (T-2) and then $1 / 2$ (T1/2), 2 (T2), 3 (T3), 5 (T5) and 7 (T7) hours after the morning meal. Blood was withdrawn from the jugular vein into heparinized tubes and immediately centrifuged. The plasma was separated into $2-\mathrm{ml}$ cupules and stored at $-80^{\circ} \mathrm{C}$.

Three-gram samples of liver and of rectus abdominis muscle were taken at slaughter and immediately frozen in liquid nitrogen at $-80^{\circ} \mathrm{C}$ before storage. An additional liver sample was taken from each calf for histological study and fixed in $10 \%$ neutral formaldehyde. 
Analysis. - Plasma non-esterified fatty acid (NEFA) content was determined titrimetrically after extraction with isopropanol-heptane 4/1 (V/V) (Trout, Estes and Friedberg, 1960). Plasma triglycerides (TG) were estimated leaving out free glycerol which varies from $10 \%$ after the meal to $3 \%$ at the end of the day (D. Durand, unpublished results). After triglyceride hydrolysis through the action of microbial lipase, the free glycerol was converted into colored formazan (Dow Chemical system) and TG was obtained by mutiplying the total glycerol by 8.76 which is the ration of tripalmitin molecular weight to glycerol molecular weight. Plasma free cholesterol (FC) was determined after cholesterol oxidase action and total cholesterol (TC) after the combined action of cholesterol esterase and cholesterol oxidase (CHO-iodine method, Merckotest). Plasma esterified cholesterol (EC) was determined by the difference between TC and FC ; plasma cholesterol esters (CE) were obtained by multiplying EC by 1.68 which is the ratio of cholesterol oleate molecular weight to cholesterol molecular weight.

Lipid infiltration into the liver was studied on frozen liver samples. Eight- $\mu \mathrm{m}$ thick slices, prepared with a cryostat, were fixed for $5 \mathrm{~min}$ in a Baker formaldehyde-calcium mixture and stained in oil Red 0 . Hepatic lesions were sought on histological samples kept in formol and included in paraffin ; 4- $\mu \mathrm{m}$ thick slices were stained in hemalun-eosin-safran. Hepatocyte glycogen overacculumation was sought on 4- $\mu \mathrm{m}$ thick slices of liver fixed in paraffin (HotchkissMcManus-Lillie) with periodic acid-Schiff (PAS) staining.

Lastly, the lipid content in liver and muscle samples was determined. The total lipids were extracted as described by Folch, Lees and Sloane-Stanley (1957). A known amount of methylheptadecanoate, added to the sample before extraction was used as an internal standard. The main lipid classes were separated by thin-layer chromatography on chromarods and quantitifed in a flame ionization detector (Ackman, 1981) using an iatroscan TH 10 analyser coupled with a Delsi electronic recording and integrating apparatus (Enica 10). The response coefficient for the different lipid classes was obtained from analysis of a standard mixture of cholesterol heptadecanoate, methyl heptadecanoate, free heptadecanoic and glyceryl triheptadecanoate, free cholesterol and phosphatidyl choline (Sigma); the composition of this mixture was close to that of the samples.

The data were processed with a 3-factor variance analysis (Snedecor and Cochran, 1971) for age effects, time of sampling and sorbitol supplementation. In the case of muscle lipid content, the variances were significantly different so that the different pairs of results were compared with a U-test (non-parametric method of Mann-Whitney, 1969).

\section{Results.}

1) Plasma non-esterified fatty acids. - The addition of sorbitol to milk substitutes did not strongly alter plasma NEFA contents. Whatever the diet, NEFA varied similarly after the meal at every age. This level was usually high at T-2, T1/2 and $\mathrm{T7}$ and lower at T2, T3 and T5 (fig. 1). Nevertheless, some data on all the calves 
of one of the two groups were distinct from the corresponding data and remained higher; these data occurred sporadically with one of the two diets, at one sampling, or at one age.

In the whole set of samples from the beginning or the end of the day (fig. 2A), as well as in those withdrawn 2 to $5 \mathrm{~h}$ after the meal (fig. 2B), NEFA
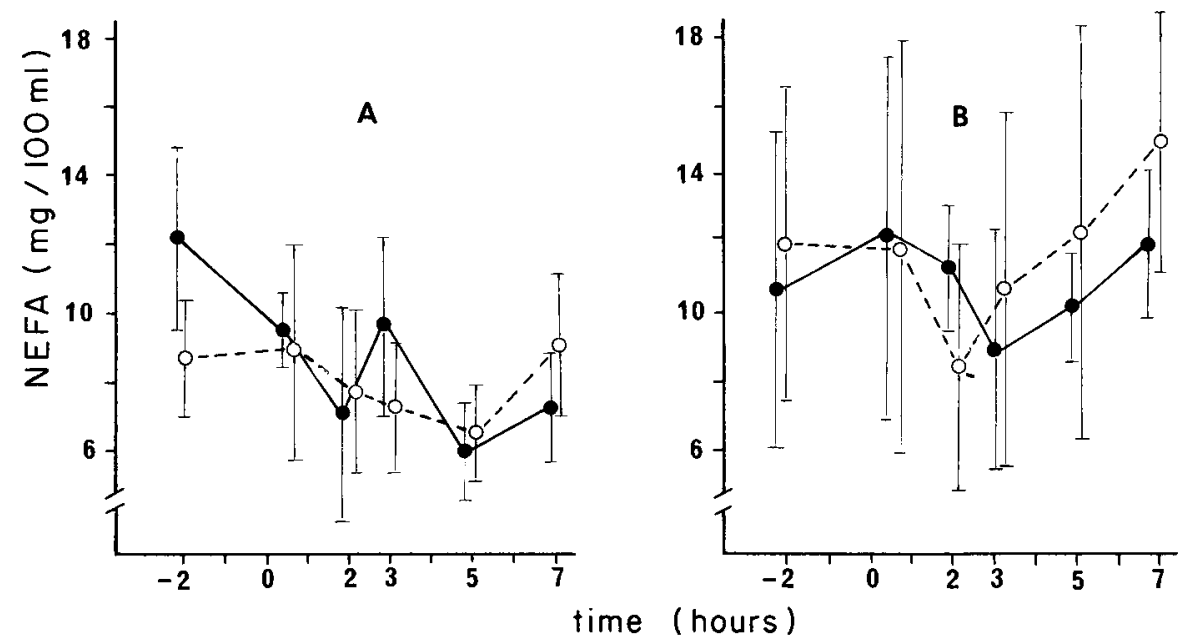

FIG. 1. - Postprandial variation in plasma NEFA in 2 (A) or 7 (B)-week old preruminant calves fed either a control $(\bullet)$ or a sorbitol (O) milk substitute (means \pm SD).
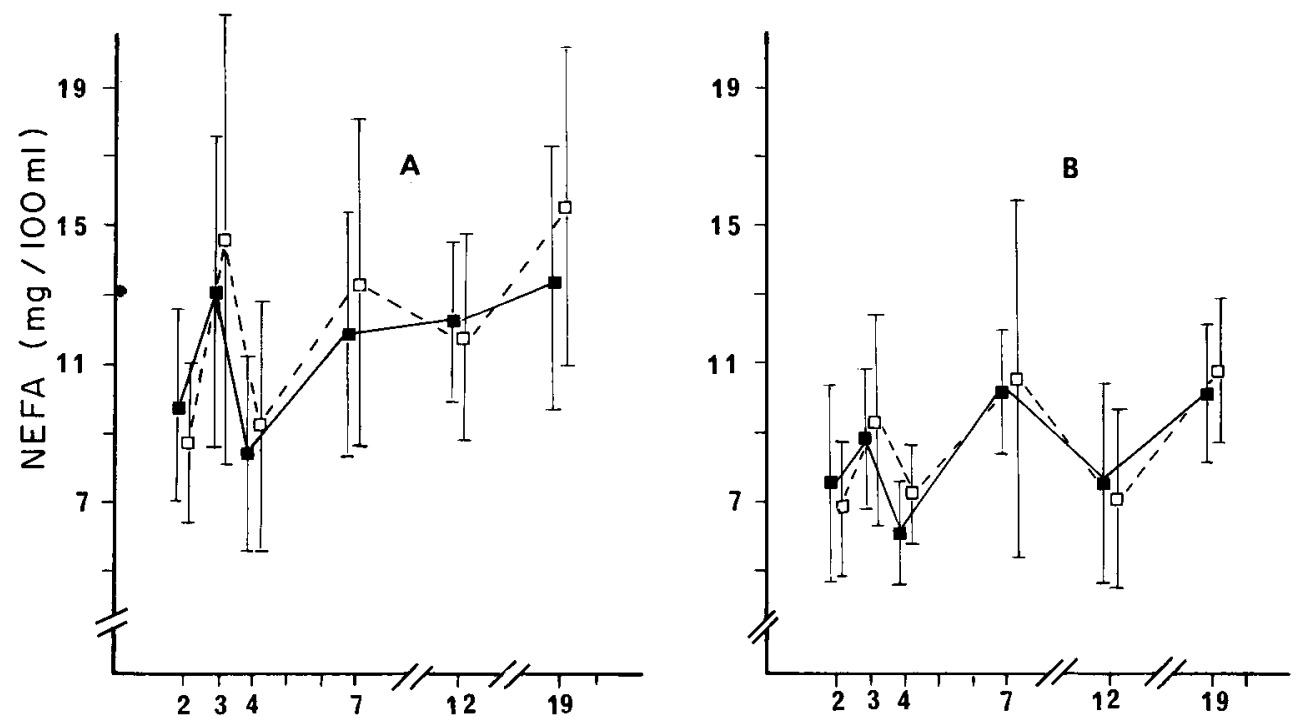

oge (weeks)

FIG. 2. - Variation in plasma NEFA in preruminant calves fed either a control (D) or a sorbitol $(\square)$ milk substitute between 2 and 19 weeks of age (A: T-2, T1/2, and T7 values; B : T2, T3 and T5 values) (means \pm SD). 
concentrations were similar in both groups of calves at each age. Nevertheless, they were significantly $(\mathrm{P}<0.05)$ lower at $T-2$ at week 2 , while they were significantly $(P<0.05)$ higher at the same time at week 19 in the calves fed sorbitol. Variance analysis (table 1) showed that individual scattering accounted

TABLE 1

Analysis of variance of calf plasma lipids as affected by sorbitol intake, age and time of sampling.

\begin{tabular}{|c|c|c|c|c|c|}
\hline \multirow{3}{*}{ Source of variation } & \multirow{3}{*}{$\begin{array}{c}\text { Degree } \\
\text { of } \\
\text { freedom }\end{array}$} & \multicolumn{4}{|c|}{ Type of plasma lipids } \\
\hline & & NEFA & TG & FC & $\mathrm{CE}$ \\
\hline & & MSS & MSS & MSS & MSS \\
\hline Diet (D) & 1 & $3422(1)$ & 26 NS & $447^{* *}$ & $18385^{* *}$ \\
\hline Time of sampling $(\mathrm{T})$ & 5 & $36477^{* *}$ & $8380^{* *}$ & $141^{* *}$ & 1622 NS \\
\hline Age of the calves (A) & 5 & $48187^{* *}$ & $5686^{* *}$ & $704^{* *}$ & $87601^{* *}$ \\
\hline$D \times T$ & 5 & 1277 NS & $508^{*}$ & $20 \mathrm{NS}$ & $90 \mathrm{NS}$ \\
\hline$D \times A$ & 5 & $21 \mathrm{NS}$ & $136 \mathrm{NS}$ & $96^{* *}$ & $3675^{*}$ \\
\hline$T \times A$ & 25 & $1878^{*}$ & $684^{* *}$ & $79 * *$ & $28 \mathrm{NS}$ \\
\hline Error & 638 & 1162 & 225 & 24 & 1383 \\
\hline
\end{tabular}

NEFA : non-esterified fatty acids ; TG : triglycerides ; FC : free cholesterol ; CE : cholesterol esters ; MSS : mean sum of squares. NS = non significant.

(1) $: 0.05<P<0.10 ;{ }^{*}: P<0.05 ;{ }^{* *}: P<0.005$.

for $60 \%$ of the total variation. The mean $5 \%$ increase in plasma NEFA concentration in calves fed sorbitol was not significant $(0.05<P<0.10)$. Variations in plasma NEFA content with calf age $(10 \%$ of total variation) or with sampling time $(18 \%$ of total variation) were highly significant $(P<0.005)$.

2) Plasma triglycerides. - As for NEFA, sorbitol intake did not alter the total plasma glycerol content. Postprandial variations in plasma triglycerides followed the same pattern as those of NEFA (fig. 3). Plasma triglycerides, which decreased 2 to $5 \mathrm{~h}$ after the meal (about $25 \%$ ), were not more homogeneous and did not deviate as much as NEFA did. In both sampling series at the beginning or the end of the day (fig. $4 \mathrm{~A}$ ) or from 2 to $5 \mathrm{~h}$ after the meal (fig. 4B), mean triglyceridemia was similar for both groups of calves at each age studied.

Variance analysis (table 1) showed that individual scattering accounted for $69 \%$ of the total variation. Postprandial variations in triglyceridemia accounted for $14 \%$ of the total variation ( $P<0.001)$. Lastly, the mean values of triglyceride content decreased regularly from week 2 to week 7 (fig. $4 ; 25$ to $30 \%$ decreasel, and then rose to high values during week 12 before decreasing again up to week 19 (20\% decrease but only for samples T-2, T1/2 and T7; fig. 4A). These variations according to calf age were significant $(P<0.001)$ and accounted for $12 \%$ of the total variation.

3) Plasma cholesterol. - In the calves given the milk substitutes containing sorbitol, plasma free cholesterol content was significantly lower $(P<0.05)$ during 


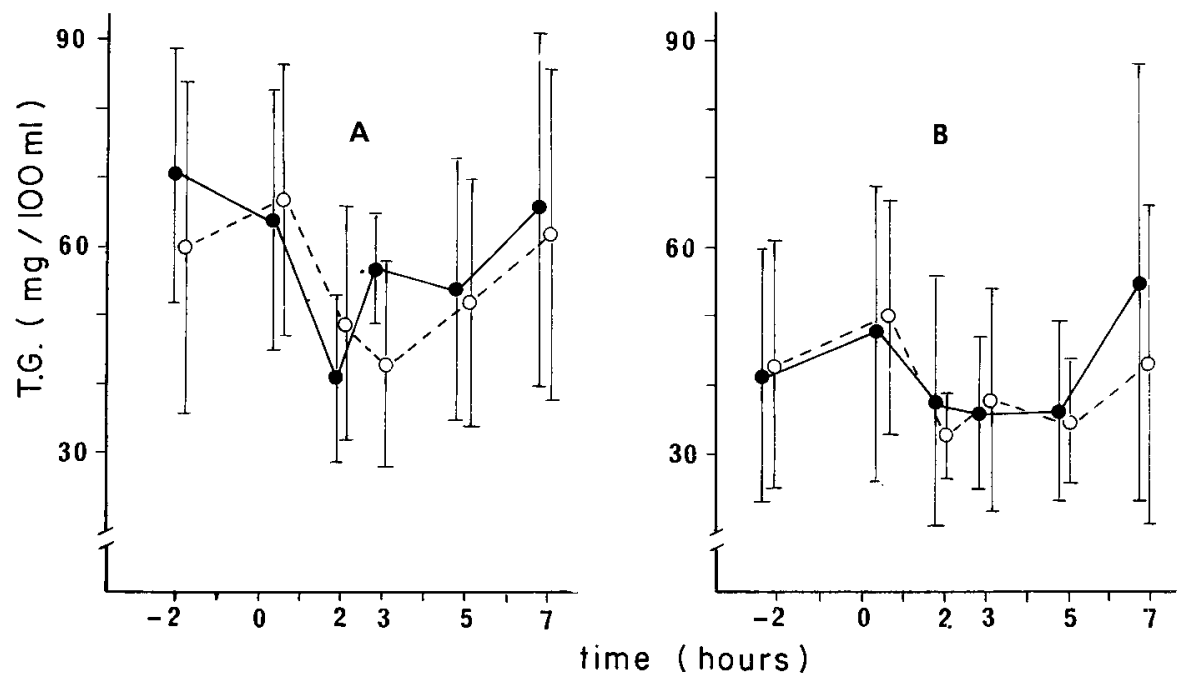

FIG 3. - Postprandial variation in plasma triglycerides in 2 (A) or 7 (B)-week old preruminant calves fed either a control $(\bullet)$ or a sorbitol $(0)$ milk substitute (means \pm SD).
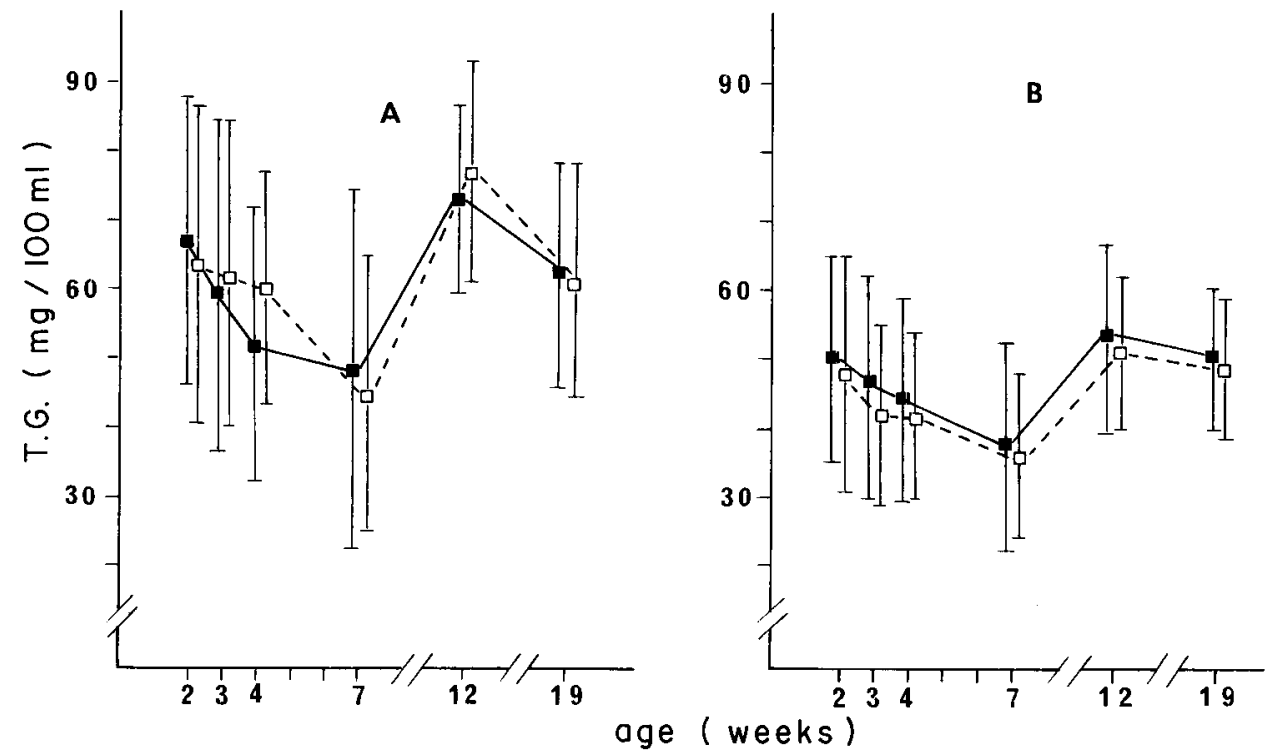

FIG. 4. - Variation in plasma triglycerides in preruminant calves fed either a control $\square$ or a sorbitol ( $\square$ ) milk replacer between 2 and 19 weeks (A : means \pm SD of $T-2, T 1 / 2$, and 77 values; $B$ : means \pm SD of $T 2, T 3$ and $T 5$ values).

week $2(30 \%)$, week 7 (75 to $95 \%$ ) and week 12 (about $55 \%$ ) (figs. 5, 6). On the whole, variance analysis (table 1) confirmed that the effects of sorbitol were significant $(P<0.001)$ and varied significantly $(P<0.005)$ with calf age. 
As in the case of NEFA or TG, plasma FC was usually lower after the meal than at the beginning or the end of the day (fig. 5). Variance analysis showed that this decrease $(30 \%$ on the average) was significant $(P<0.05)$ and varied with

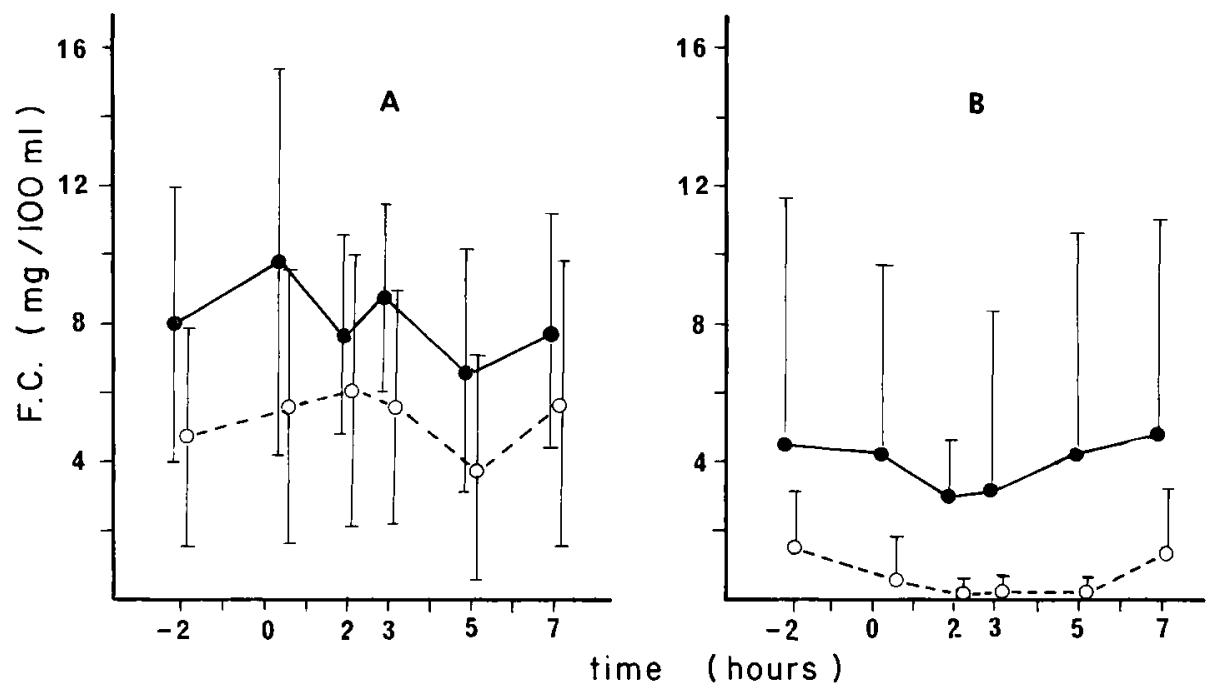

FIG. 5. - Postprandial variation in plasma free cholesterol in 2 (A) or 7 (B)-week old preruminant calves fed either a control $(\bullet)$ or a sorbitol (O) milk substitute (means \pm SD).

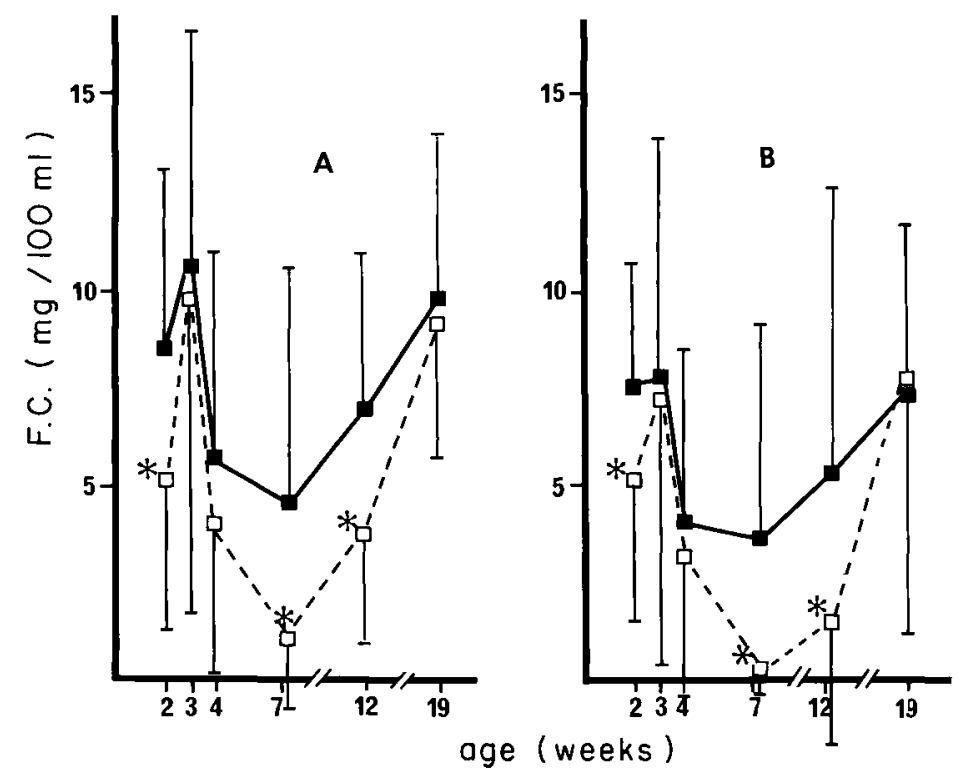

FIG. 6. - Variation in plasma free cholesterol in preruminant calves fed either a control (a) or a sorbitol (口) milk replacer between 2 and 19 weeks (A: T-2, T1/2 and T7 values; $\mathrm{B}: \mathrm{T} 2, \mathrm{~T} 3$ and T5 values). 
age $(P<0.05)$. The addition of sorbitol had effects in both sampling periods (fig. 6) but their extent varied with the sampling time $(P<0.025)$. Finally, plasma $F C$ content varied with age as did TG. These variations were highly significant $(P<$ 0.001).

4) Plasma cholesterol esters. - The addition of sorbitol to the milk substitute also decreased plasma CE (figs. 7,8$)$ during week $2(10 \% ; P<0.001)$, week 7 (25\%; NS) and week $12(10 \% ; P<0.005)$ as well as the interaction with age $(\mathrm{P}<0.01)$.
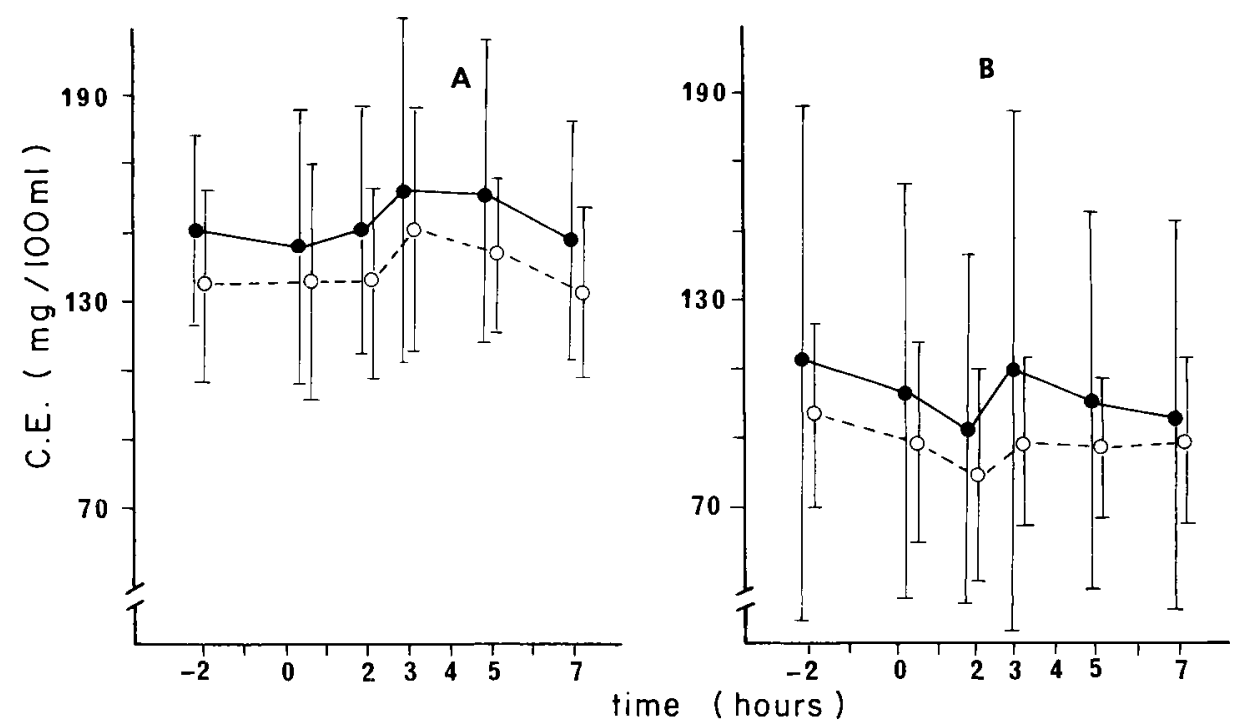

FIG. 7. - Postprandial variation in plasma cholesterol esters in 2 (A) or 7 (B)-week old preruminant calves fed either a control $(\bullet)$ or a sorbitol $(O)$ milk substitute (means \pm SD).

In contrast with the other classes of plasma lipid, plasma CE content did not show any marked variations after the meal (fig. 7). However, it did vary significantly with age $(P<0.001)$, being at a minimum during week 7 (98 \pm 61 vs $74 \pm 25 \mathrm{mg} / 100 \mathrm{ml}$ plasma in the control vs sorbitol calves, respectively) and rising to the highest level at the end of the experiment $(170 \mathrm{mg} / 100 \mathrm{ml}$ plasma on the average).

5) Liver

a) Liver lipid composition and content. - The total lipid contents of the liver of control and sorbitol calves were similar $(32.1 \pm 3.8$ and $29.9 \pm 2.0 \mathrm{mg} / \mathrm{g}$ fresh tissue, respectively). Lipid composition was also the same for both groups (table 2) ; phospholipids, FC, TG, CE and NEFA amounted to 91.3, 4.5, 3.3, 0.9 and $1.1 \%$, respectively, of the total lipid. 
TABLE 2

Effects of sorbitol intake on the lipid content in preruminant calf liver (mean $\pm \mathrm{SD} ; \mathrm{mg} / \mathrm{g}$ fresh tissue) from 2 to 19 weeks of age (control group, $\mathrm{n}=10$; sorbitol group, $\mathrm{n}=9$ ).

\begin{tabular}{|c|c|c|}
\hline Group & Control & Sorbitol \\
\hline 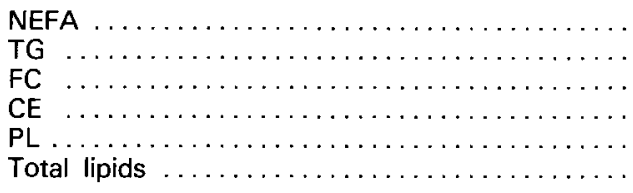 & $\begin{array}{r}0.36 \pm 0.15 \\
1.08 \pm 0.32 \\
1.31 \pm 0.24 \\
0.22 \pm 0.06 \\
29.50 \pm 6.81 \\
32.47 \pm 7.02\end{array}$ & $\begin{array}{r}0.35 \pm 0.11 \\
0.94 \pm 0.20 \\
1.31 \pm 0.11 \\
0.30 \pm 0.12 \\
27.12 \pm 1.78 \\
30.02 \pm 1.97\end{array}$ \\
\hline
\end{tabular}

NEFA $=$ non-esterified fatty acids $; \mathrm{TG}=$ triglycerides; $\mathrm{FC}=$ free cholesterol ; $\mathrm{CE}=$ cholesterol esters $; \mathrm{PL}=$ phospholipids.

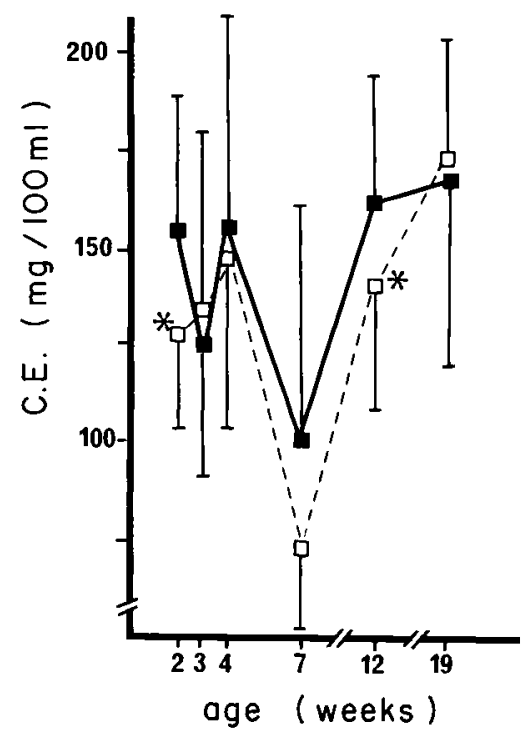

FIG. 8. - Variation in plasma cholesterol esters in preruminant calves fed either a control $\square$ ) or a sorbitol ( $\square$ ) milk replacer between 2 and 19 weeks.

b) Histology. - An anatomo-pathological study confirmed the absence of severe hepatic lesions, namely of massive steatosis, in both groups of calves. A steatosed area was observed however in the liver of one control calf. In both groups, some calves showed physiological over-accumulation of glycogen as well as some non-specific inflammatory infiltration (table 3).

6) Muscle lipids. - Total lipid content in the rectus abdominis muscle was twice higher $(P<0.05)$ in control than in sorbitol calves $(26.1 \pm 8.9 \mathrm{mg} / \mathrm{g}$ fresh tissue vs $13.6 \pm 2.8 \mathrm{mg} / \mathrm{g}$ ). This difference was essentially linked to the TG content of the muscle (table 4) which was 2.7 times higher in the control calves $(P<0.05)$. The FC content of this muscle was also 1.6 times higher $(P<0.01)$ in the control group. Otherwise, only traces of cholesterol esters were found in the muscles $1<0.05 \mathrm{mg} / \mathrm{g}$ fresh tissue), while PL or NEFA content did not differ between the 
groups. The coefficient of variation of the muscle lipid content was higher in the control $(34.1 \%)$ than in the sorbitol $(20.5 \%)$ group.

\section{TABLE 3}

Effects of sorbitol intake from 2 to 19 weeks of age on the anatomopathologic status of the liver of preruminant calves at slaughter (number of calves in each class).

\begin{tabular}{ccccccccc}
\hline \multirow{2}{*}{ Group } & \multicolumn{3}{c}{ Lipid infiltration $\left({ }^{1}\right)$} & \multicolumn{3}{c}{ Inflammatory lesions $\left({ }^{2}\right)$} & \multicolumn{2}{c}{ Glycogen accumulation $\{3)$} \\
\cline { 2 - 8 } & 0 & 1 & 2 & 0 & 1 & 2 & 0 & 1 \\
\hline Control $\ldots \ldots \ldots$ & 6 & 3 & 1 & 2 & 6 & 2 & 4 & 6 \\
Sorbitol $\ldots \ldots \ldots$ & 8 & 1 & 0 & 4 & 4 & 1 & 5 & 4 \\
\hline
\end{tabular}
cells).

(1) Oil red 0 staining $(0=$ no stained cells ; $1=$ scattered stained cells ; $2=$ numerous stained

(2) Hemalun-eosin-safran staining $10=$ no lesions; $1=$ histiolymphocite lesions ; $2=$ microgranulocyte lesions).

(3) P.A.S. Hotchkiss-McManus-Lillie staining $(0=$ no glycogen-rich cells ; $1=$ some glycogenrich cells).

TABLE 4

Effects of sorbitol intake on rectus abdominis muscle lipids (mean $\pm \mathrm{SD} ; \mathrm{mg} / \mathrm{g}$ fresh tissue) in preruminant calves (control group, $\mathrm{n}=10$; sorbitol group, $\mathrm{n}=9$ ).

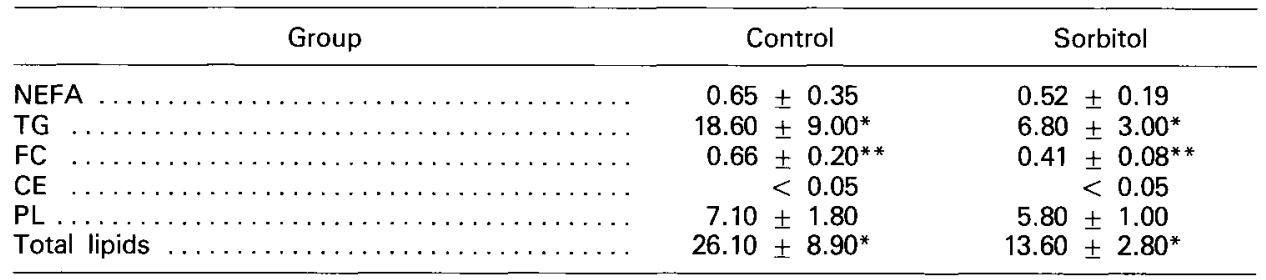

$\mathrm{NEFA}=$ non-esterified fatty acids $; \mathrm{TG}=$ triglycerides $; \mathrm{FC}=$ free cholesterol $; \mathrm{CE}=$ cholesterol esters; $\mathrm{PL}=$ phospholipids.

Significant difference : ${ }^{*} \mathrm{P}<0.05 ;{ }^{*} \mathrm{P}<0.01$.

\section{Discussion.}

Plasma lipids in control calves. - Postprandial variation in plasma lipids in the present study agree, on the whole, with data obtained elsewhere on preruminant calves (Bazin and Brisson, 1976 ; Toullec Guilloteau and Coroller, 1979 ; Bauchart and Aurousseau, 1981 ; Grizard et al., 1982 ; Bauchart, 1983). Nevertheless, the concentrations of total glycerol and of free and esterified cholesterol in the present experiment were significantly higher $(+50$ to $+100 \%)$ than those found previously (Grizard et al., 1982 ; Bauchart, 1983). Moreover, in the studies of Wood, Bailey and McLeod (1971, Wrenn et al. (1980) and Bauchart (1983), lipemia reached a maximum after 2 or 4 weeks. In the present study, the higher values observed in the young calves declined slowly and only reached the normal level after 7 weeks ; this could be the result of a slower adaptation of the lipid 
metabolism of the calves offered the higher level of lipid-rich milk. The enhancement of lipemia as well in the present study during weeks 12 and 19 has not been described before. It also might be due to a new phase of adaptation to an increased level of milk intake after week 10.

Plasma lipids in sorbitol calves. - As already observed (Bauchart, 1983), the hypocholesterolemic effects of sorbitol in week 2 were obtained during weeks 7 and 12 as well, confirming previous observations in humans (Berg, Matzkies and Bergner, 1973 ; Berg and Matzkies, 1975). This sorbitol effect is directly related to a decreased hepatic output of cholesterol (Durand, Bauchart and Lefaivre, 1984). Both the hypocholesterolemic effect of sorbitol itself and the discontinuity of its effects could be accounted for by the conversion of sorbitol into fructose in the hepatic cells.

Cholesterol synthesis has been found to be inhibited by lactate accumulation in the rat liver (Beynen et al., 1982). Sorbitol is converted into fructose in the bovine liver (Frahm, Graf and Krausslich, 1977) and can increase lactacidemia as in rats or humans (Bassler and Stein, 1967 ;. Papenberg, 1971; Keller and Froesch, 1972 ; Berry, Kun and Werner, 1973 ; Willgerodt and Beyreiss, 1974). Thus, moderate doses of fructose have a hypocholesterolemic effect in rats or humans, while higher doses have no effect (Blakely et al., 1982 ; Hallfrisch, Reiser and Prather, 1983).

The fact that sorbitcl no longer had any effect after week 2 could be related to the increase in cetose-1-phosphate aldolase which allowed the fructose to be completely disposed of within a short time; the intravenous administration of fructose in newborn babies initially increases fructosemia, but after a few days it no longer accumulates in the blood and its effects disappear (Schwartz et al., 1964). Similarly, in young preruminant calves (Daniels et al., 1981) as well as in piglets (Brenner and Kolb, 1976), the initial increase of fructosemia after high levels of sorbitol intake disappears after 7 or 12 days of treatment.

In older calves (week 19), increased sorbitol intake seemed to go along with a reduced cetose-1-phosphate aldolase activity (Howarth, Baldwin and Ronning, 1968), again increasing fructose accumulation in the liver. Sorbitol intake might have been too high during week 19 and, as in rabbits (Strack et al., 1965), its hypocholesterolemic effects would cease as excess fructose was released from the liver.

In other respects, sorbitol might also contribute to lowering plasma cholesterol since it can increase the production of bile salts from the liver into the intestine (Thivend et al., 1984).

Tissue lipids in sorbitol calves. - The effects of sorbitol intake on the composition and concentration of liver or muscle lipids have never been described before in calves. Sorbitol did not have any effect on the liver in either the biochemical or histological study. Despite high lipid intake, the calves, namely the control calves, did not show any trace of steatosis. Moreover, sorbitol was not 
able to alter liver lipids, most likely due to the intensive uptake and release of lipoproteins by the liver (Hay et al., 1971 ; Blum, Levy and Eisenberg, 1977).

In contrast, muscle TG and $\mathrm{FC}$ were considerably reduced by sorbitol. The muscle TG in the control calves $(18.6 \pm 9.0 \mathrm{mg} / \mathrm{g}$ fresh tissue) can be compared to data obtained on calves fed a milk substitute containing $21 \%$ of fat and slaughtered at $170 \mathrm{~kg}$ body liveweight $(15.5 \pm 4.7 \mathrm{mg} / \mathrm{g}$ fresh tissue) (Aurousseau, unpublished data). The decreased TG and FC contents in the rectus abdominis muscle did not depend on calf growth rate (figs. 9A, 9B) but appeared to be directly related to the effect of the sorbitol on lipid metabolism.

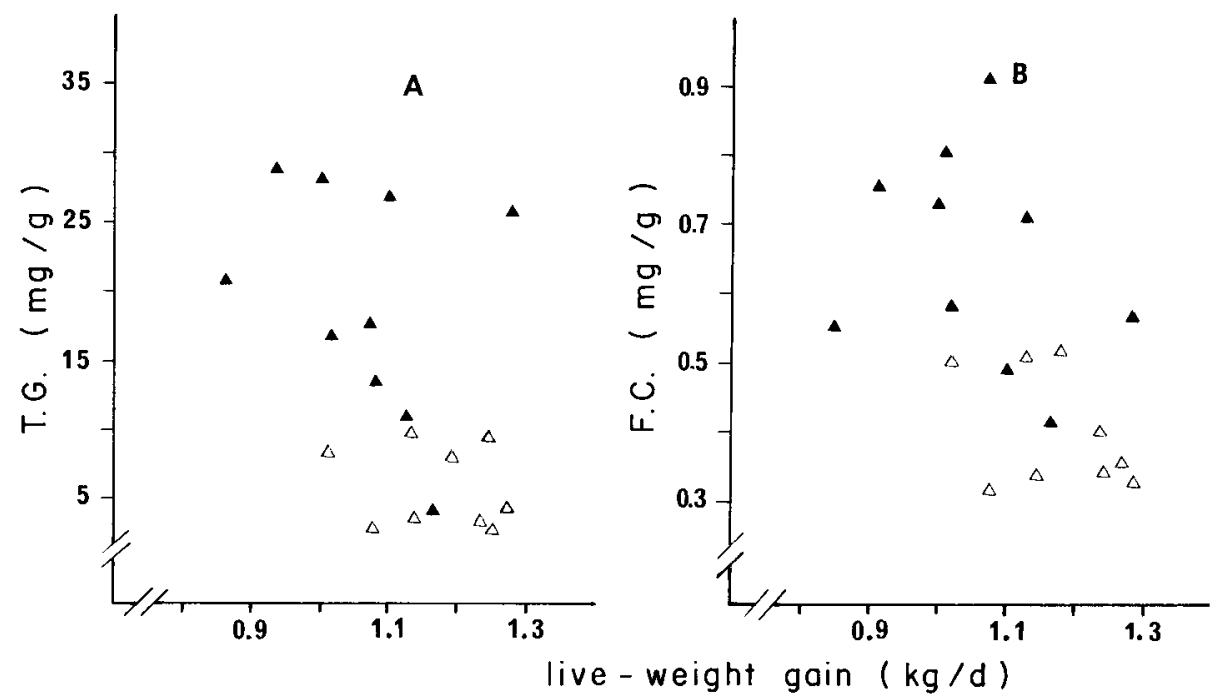

FIG. 9. - Relationships between muscle triglyceride (A) or free cholesterol (B) contents and daily liveweight gain in preruminant calves fed either the control $(\Delta)$ or the sorbitol $(\Delta)$ milk substitute for 18 weeks.

The decrease in TG content in the rectus abdominis muscle to $6.8 \pm 3.0$ $\mathrm{mg} / \mathrm{g}$ fresh tissue after sorbitol might have been obtained in two ways : (1) sorbitol decreased the output of ketone bodies from the liver (Exton and Edson, 1964 ; Berg and Matzkies, 1975), promoting the oxidative catabolism of NEFA in the muscle and lowering its energy supply ; (2) fructose derived from sorbitol in the liver (Frahm, Graf and Krausslich, 1977) could have increased the uptake of blood NEFA by that organ (Topping and Mayes, 1972 ; Gardner and Mayes, 1974) and their utilization for lipoprotein synthesis by liver, and, conversely, have decreased NEFA uptake by the muscle. In other respects, the $40 \%$ decrease in the FC content of the rectus abdominis muscle in sorbitol-fed calves supports the notion that the lowered cholesterolemia was really obtained due to a lower rate of cholesterol output from the liver and was not owing to a faster rate of peripheral tissue uptake. 
It should be noted that the coefficients of variation for muscle FC or TG content were low in the sorbitol calves and far higher in the control calves. The highest TG or FC content was obtained in the muscle of control calves which showed health disorders (diarrhoea, liveweight loss or growth plateau) during the experiment.

\section{Conclusion.}

These results emphasize that the usefulness of adding sorbitol to a milk replacer fed to preruminant calves is not limited to the previously reported effects of this component on the feed conversion ratio (Bauchart, Aurousseau and Auclair, 1984). The clear-cut hypocholesterolemic effects of sorbitol led to lower muscle FC content in the corresponding calves. The muscle TG content also declined after sorbitol intake which favoured the dietetic quality of the meat.

This study of blood and tissue lipids supports the hypothesis that the improved growth noted in calves receiving sorbitol is obtained when the organism, especially the liver, reaches its physiological limits. Further complementary work is needed to determine age variations in the ability of the organism to metabolize sorbitol. Also, the pathways of cholesterol synthesis inhibition and the decrease in muscle TG content need to be studied.

Reçu en juin 1984.

Accepté en novembre 1984.

Acknowledgements. - The authors wish to express their gratitude to the company "Roquette Frères " (62136 Lestrem, France) for financial support and for providing the milk replacers used in this study and to $P$. Thivend and his team for technical assistance.

Résumé. - Addition de sorbitol à un lait de remplacement pour veaux de boucherie. - II. Influence sur les lipides du plasma, du foie et du muscle.

Deux groupes homologues de 10 (lot témoin) et 9 (lot Sorbitol) veaux mâles préruminants croisés Frison-Holstein ont été utilisés pour étudier les effets du sorbitol sur le métabolisme lipidique. Ils ont reçu, entre les âges de 1 et de 8 semaines, 2 aliments d'allaitement (IC, IS) riches en protéines et en matières grasses (23\% de MS), puis entre les âges de 8 et 19 semaines, 2 aliments (FC, FS) dont les teneurs en protéines et en matières grasses étaient moins élevées ( $21 \%$ de MS). Les aliments IC et FC étaient dépourvus de sorbitol, tandis que les aliments IS et FS en contenaient $0,8 \%$ par rapport à la matière sèche.

Des prélèvements de sang ont été effectués aux âges de $2,3,4,7,12$ et 19 semaines et aux temps suivants : $2 \mathrm{~h}$ avant (T-2), puis $1 / 2(\mathrm{~T} 1 / 2), 2$ (T2), 3 (T3), 5 (T5) et $7 \mathrm{~h}$ (T7) après la prise de repas du matin. A l'abattage à 19 semaines, des échantillons de foie et de muscle rectus abdominis ont été prélevés sur les carcasses.

L'addition de sorbitol dans les laits de remplacement a été sans effet sur les teneurs du plasma en acides gras non estérifiés ou en triglycérides. Mais les teneurs en cholestérol libre et estérifié ont été significativement diminuées en $2^{e}, 7^{e}$ et $12^{e}$ semaines (respectivement de 60 et de $15 \%$ en moyenne).

L'ingestion de sorbitol a réduit significativement les teneurs du muscle en triglycérides $(6,8 \mathrm{mg} / \mathrm{g}$ de tissu frais au lieu de 18,6$)$, en cholestérol libre $(0,41 \mathrm{mg} / \mathrm{g}$ au lieu de 0,66$)$ et en lipides totaux $(13,6 \mathrm{mg} / \mathrm{g}$ au lieu de 26,1$)$.

Reproduction Nutrition Développement, $n^{\circ} 2-85,-6$. 
Enfin, la composition en lipides des foies n'a pas été modifiée par l'ingestion de sorbitol. L'étude histologique a confirmé l'absence de lésions graves avec les régimes.

De manière générale, la dispersion des résultats a été beaucoup plus élevée chez les animaux du groupe témoin que chez ceux du groupe sorbitol.

\section{References}

ACKMAN R. G., 1981. Flame-ionization detection applied to thin-layer chromatography on coated quartz rods. Methods in Enzymology, 82, 205-252.

BASSLER K. H., STEIN G., 1967. Biochemische Grundlagen für wirkungsunterschiede wischen Sorbit und Fructose. Hoppe. Seyler's Z. Physiol. Chem., 348, 533-539.

BAUCHART D., 1983. Evolution avec l'âge de la cholestérolémie et de la triglycéridémie postprandiales chez le veau préruminant; influence de l'ingestion de sorbitol. Reprod. Nutr. Dévelop., 23, 81-92.

BAUCHART D., AUROUSSEAU B., 1981. Postprandial lipids in blood plasma of preruminant calves. J. Dairy Sci., 64, 2033-2042.

BAUCHART D., AUROUSSEAU B., AUCLAIR E., 1985. Addition of sorbitol to a milk-substitute for veal calves. 1. Effect on health, growth and feed conversion. Reprod. Nutr. Dévelop., 25, 399-410.

BAZIN A. C., BRISSON G. J., 1976. Plasma lipids, ketone bodies, and glucose concentrations in calves fed high and low-fat milk replacers. J. Dairy Sci., 59, 1301-1305.

BERG G., MATZKIES F., 1975. Serumlipoproteide und Ketonkörper nach intravenöser dauer Infusion von Sorbit. Clin. Wschr., 53, 187-188.

BERG G., MATZKIES F., BERGNER D., 1973. Verhalten der Serumlipoproteide nach Langzeitinfusion von Xylit, Fruktose und Sorbit bei gesunden Männern. Klin. Wschr., 51, 1124-1125.

BERRY M. N., KUN E., WERNER H. V., 1973. Regulatory role of reducing-equivalent transfer from substrate to oxygen in the hepatic metabolism of glycerol and sorbitol. E. J. Biochem., 53, 407-417.

BEYNEN A. C., BUECHLER K. F., VAN DER MOLEN A. J., GEELEN M. J. H., 1982. The effects of lactate and acetate on fatty acid and cholesterol biosynthesis by isolated rat hepatocytes. Int. J. Biochem., 14, 165-169.

BLAKELY S. R., HALLFRISCH J., REISER S., PRATHER E. S., 1982. Long-term effects of moderate fructose feeding on lipogenic parameters in Wistar rats. Nutr. Rep. Int., 25, 675-685.

BLUM C. B., LEVY R. I., EISENBERG S., 1977. High-density lipoprotein metabolism in man. J. clin. Invest., 60, 795-807.

BRENNER K. V., KOLB F. E., 1976. Untersuchungen über die Beeinflussung des Gehalts an Sorbit, Glucose, Fruktose und Laktat in Blut von Rindern, Schafen und Ferkeln durch parenterale Verabreichung von Sorbitlösung. Arch. exper. vet. Med., Leipzig, 30, 109-119.

DANIELS L. B., PETERSON R. L., PIPER E. L., RAKES J. M., 1981. Sorbitol in diet of young dairy calves. J. Dairy Sci., 64, 449-453.

DURAND D., BAUCHART D., LEFAIVRE J., 1984. In vivo hepatic balance of lipids and glucose in the calf; effect of sorbitol intake. Can. J. anim. Sci., 64 (suppl.), 238-239.

EXTON J. H., EDSON N. L., 1964. The antiketogenic action of sorbitol. Biochem. J., 91, 478-483.

FOLCH J., LEES M., SLOANE-STANLEY G. H., 1957. A simple method for the isolation and purification of total lipids from animal tissues. J. biol. Chem., 226, 497-509.

FRAHM K., GRAF F., KRAUSSLICH H., 1977. Enzymaktivitäten in Rinderorganen. Zbl. Vet. Med A, 24, 81-87.

GARDNER R., MAYES P. A., 1974. The singular and combined effects of acute fructose loading and adaptation to a high sucrose diet on hepatic very-low density-lipoprotein secretion. Biochem. Soc. Trans, 2, 1127-1128.

GRIZARD J., TOULLEC R., GUILLOTEAU P., PATUREAU-MIRAND P., 1982. Influence de la 
cinétique d'évacuation gastrique de l'aliment sur l'insulinémie chez le veau préruminant. Reprod. Nutr. Dévelop., 22, 475-484.

HALLFRISCH J., REISER S., PRATHER E. S., 1983. Blood lipid distribution of hyperinsulinemic men consuming three levels of fructose. Am. J. clin. Nutr., 37, 740-748.

HAY R. V., POTTENGER L. A., REINGOLD A. L., GESTS G. S., WISSLER R. W., 1971. Degradation of $\mathrm{I}^{125}$ labelled serum low density lipoprotein in normal and oestrogen-treated male rats. Biochem. Biophys. Res. Commun., 44, 1471-1477.

HERS H. G., 1954. The conversion of fructose 1. $\mathrm{C}^{14}$ and sorbitol 1. $\mathrm{C}^{14}$ to liver and muscle glycogen in the rat. J. biol. Chem., 214, 373-381.

HOSHI M., 1963. Clinical application of sorbitol in patients with diabetes mellitus and in patients with liver disease. Med. J. Osaka Univ., 14, 47-60.

HOWARTH R. E., BALDWIN R. L., RONNING M., 1968. Enzyme activities in liver, muscle and adipose tissue of calves and steers. J. Dairy Sci., 51, 1270-1274.

KELLER U., FROESCH E. R., 1972. Vergleichende Untersuchungen über den Stoffwechsel von Xylit, Sorbit und Fruktose beim Menschen. Schweiz. Med. Wschr., 102, 1017-1022.

KOUIDER S., KOLB E., MULLER E., 1980. Untersuchungen über den Einfluss der intravenösen Verabreichung von Sorbitlösung auf den Gehalt des Blutplasmas von Kälbern, Jungrindern und Rindern an sorbit, fruktose, glukose, insulin und freien Fettsäuren sowie über die Halbwertszeit des Sorbits. Arch. exper. vet. Med. Leipzig, 2, 193-203.

MANN J., WHITNEY K., 1969. Les tests non paramétriques: buts et principaux tests. In Méthodes statistiques à l'usage des médecins et biologistes, 245-247, Ed. Flammarion Médecine Science, Paris.

PAPENBERG J., 1971. Regulation of gluconeogenesis with ethanol and fructose by the isolated perfused rat liver, 145-152. In H. D. SOLING, B. WILLMS, Regulation of gluconeogenesis, 9th Conf. of the Gesellschaft für Biologische Chemic., Georg Thieme Verlag Stuttgart.

SCHWARTZ R., GAMSU H., MULLINGAN P. B., REISNER S. H., WYBREGT S. H., CORNBLATH M., 1964. Transient intolerance to exogenous fructose in the newborn. $J$. clin. Invest., 43, 333-340.

SNEDECOR G. W., COCHRAN W. G., 1971. Méthodes statistiques. Ass. Coord. Tech. Agric. Ed., Paris, 488-496.

STRACK E., KUHFAHL E., MULLER F., BEYREISS K., 1965. Der Umsatz von Sorbit im Tierkörper unter enteralder und intravasaler Dauerinfusion. Z. Gesamt, exp. Med., 139, 23-32.

STURTON G., PRITCHARD P. H., HAN L. Y., BRINDLEY D. N., 1978. The involvement of phosphatidate phosphohydrolase and phospholipase $A$ activities in the control of hepatic glycerolipid synthesis. Effects of acute feeding with glucose, fructose, sorbitol, glycerol and ethanol. Biochem. J., 174, 667-670.

THIVEND P., 1982. Influence du sorbitol dans l'alimentation de veau de boucherie. Bull. Tech. CRZV Theix INRA, 50, 47-50.

THIVEND P., DEBARRE M., LEFAIVRE J., TOULLEC R., 1984, Influence of sorbitol on biliary secretion in the preruminant calf. Can. J. anim. Sci., 64 (suppl.), 102-103.

TOPPING D. L., MAYES P. A., 1972. Direct stimulation by insulin and fructose of very-low-density lipoprotein secretion by the perfused liver. Biochem. J., 126, 295-311.

TOULLEC R., GUILLOTEAU P., COROLLER J.-Y., 1979. Influence de la cinétique d'évacuation gastrique de l'aliment sur l'absorption chez le veau préruminant. Ann. Biol. anim. Biochim. Biophys., 19, 729-732.

TROUT D. L., ESTES E. H. Jr., FRIEDBERG S. J., 1960. Titration of free fatty acids of plasma. A study of current methods and a new modification. J. Lip. Res., 1, 199-202.

WILLGERODT M., BEYREISS K., 1974. Turnover kinetics and influence of sorbitol on the concentrations of blood glucose and lactate and on the acid base balance in newborns. Biol. Neonate, 24, 94-105.

WOOD A. S., BAILEY H. S., MacLEOD G. K., 1971. Imposing a weekly fast on calves receiving a milk replacer diet once and twice per day : blood glucose and plasma lipid patterns. J. Dairy Sci., 54, 509-514.

WRENN T. R., BITMAN J., McDONOUGH F. E., WEYANT F. R., WOOD D. L., 1980. Feeding cholesterol and tallow in liquid diet to veal calves. J. Dairy Sci., 63, 1403-1411. 